Research Paper

\title{
Prognostic significance of ZEB1 and ZEB2 in digestive cancers: a cohort-based analysis and secondary analysis
}

\author{
Huihui Chen ${ }^{1, *}$, Wei Lu ${ }^{1,3, *}$, Chongjie Huang ${ }^{2, *}$, Kefeng Ding ${ }^{1}$, Dajing $\mathrm{Xia}^{3}$, Yihua \\ $\mathbf{W u}^{3,4}$ and $\mathrm{Mao} \mathrm{Cai}^{2}$ \\ ${ }^{1}$ Department of Oncology, Second Affiliated Hospital, Zhejiang University College of Medicine, Hangzhou, China \\ ${ }^{2}$ Department of Anorectal Surgery, The Second Affiliated Hospital and Yuying Children's Hospital of Wenzhou Medical \\ University, Wenzhou, China \\ ${ }^{3}$ Department of Toxicology, Zhejiang University School of Public Health, Hangzhou, China \\ ${ }^{4}$ Department of Epidemiology and Health Statistics, Zhejiang University School of Public Health, Hangzhou, China \\ *These authors have considered co-first authors \\ Correspondence to: Mao Cai, email: caicai20012001@sina.com \\ YihuaWu, email: georgewuer@126.com
}

Keywords: ZEB family, digestive cancer, prognostic value, cohort-based analysis, secondary analysis

Received: October 02, $2016 \quad$ Accepted: November 24, $2016 \quad$ Published: February 23, 2017

Copyright: Chen et al. This is an open-access article distributed under the terms of the Creative Commons Attribution License (CC-BY), which permits unrestricted use, distribution, and reproduction in any medium, provided the original author and source are credited.

\section{ABSTRACT}

Background: Digestive cancers are common malignancies worldwide, however there are few effective prognostic markers available. In this study we comprehensively investigated the prognostic significance of ZEB1 and ZEB2 in digestive cancers.

Methods: Electronic databases were searched and studies met the selection criteria were included. Study information was recorded and quality assessment was performed according to the REMARK guideline. Hazard ratios and its corresponding $\mathbf{9 5 \%}$ confidence intervals were extracted and pooled. Sensitivity analyses, subgroup analyses, cumulative meta-analyses and secondary analyses were also performed to increase the stability and reliability of our results.

Results: 24 cohort studies were included in the study. High ZEB1 and ZEB2 levels predicted poor overall survival, meanwhile high ZEB2 levels predicted poor disease free survival for digestive cancer patients. From subgroup analyses we observed ZEB1 was found to be significantly associated with poor overall survival for patients with pancreatic cancer, gastric cancer and colorectal cancer, while ZEB2 was found to be significantly associated with poor overall survival for patients with hepatocellular carcinoma and gastric cancer. Furthermore, by conducting secondary analyses we confirmed both ZEB1 and ZEB2 played important roles in gastric cancer prediction. In addition, we found high ZEB1 and ZEB2 expression were significantly associated with depth of invasion, lymph node metastasis and TNM stage in digestive cancer patients.

Conclusions: The present study validated the prognostic value and clinicopathological association of ZEB1 and ZEB2 in digestive cancers, especially in gastric cancer.

\section{INTRODUCTION}

Digestive cancers are common malignancies featured by their invasiveness and chemo-resistance [1-3], which cause millions of cancer associated deaths worldwide every year $[4,5]$. Despite that treatments for digestive cancers have been improved recently, patients' clinical outcomes still remain unfavorable $[4,6]$. Although researchers have paid much effort to identify potential prognostic markers for digestive cancers patients, few tumor markers are put into clinical use routinely $[7,8]$. Therefore, it is essential to identify effective prognostic markers in digestive cancers. 
Metastatic property, the leading cause of about $90 \%$ of cancer patients' deaths, is the primary characteristic of cancer. Cancer cells could escape from chemotherapy via metastasizing to distant organs, which will lead to poor clinical outcomes. Epithelial mesenchymal transition (EMT) is a process during which cancer cells lose epithelial markers and then increase motility and aggressiveness $[9,10]$. Numerous cell signaling pathways are implicated with the induction and maintenance of EMT, such as TGF-beta, Wnt/beta-catenin, Notch and oncogenic Src or Ras signaling [11-14]. Zinc finger E-box binding homeobox 1 (ZEB1, also referred as TCF8, AREB6 and Zfhx1a) and zinc finger E-box binding homeobox 2 (ZEB2, also referred as SIP1, HSPC082 and Zfhx 1b) are two ZEB family transcriptional factors involved in the EMT process, which function as either transcriptional activator or repressor depending on their interplay with other transcriptional factors $[15,16]$. It is verified that ZEB family could bind to the promoter of $\mathrm{CDH} 1$ gene thus repressing the expression of epithelial marker E-cadherin [17-19]. In addition, 3' untranslated regions of ZEB family are direct target of miR-200 family, whereas promoters of miR-200 family contain highly conserved E-boxes which could be occupied by ZEB1, thus forming a negative self-enforcing feedback loop with miR-200 family [16, 20, 21]. Although accumulating evidences have suggested the oncogenic role of ZEB family, some researchers put forward that ZEB2 can suppress tumor by interacting with retinoblastoma pathway as well [22]. Therefore, further research should be carried out to comprehensively investigate the mechanisms of ZEB family in regulating tumor metastasis.

Various studies have reported aberrant expression of ZEB family members in a multitude of cancers [23-25]. However their clinical relevance in digestive cancers was inconsistent and it remained to be further explored. For example, Zhang et al. found that ZEB1 was a prognostic marker in colorectal cancer and higher expression of ZEB1 weas correlated with liver metastasis [26]. However, Otsuki et al. argued that other EMT markers such as Vimentin rather than ZEB2 predicted decreased overall survival in gastric cancer [27]. Besides, sample sizes of previous studies were relatively small, which may yield unstable results. Hence we performed this cohort-based analysis and secondary analysis to comprehensively investigate the prognostic value of ZEB1 and ZEB2 in digestive cancers.

\section{RESULTS}

\section{Search results and characteristics of the included studies}

The initial search in PubMed, EMBASE, Ovid and Cochrane Library electronic databases yielded a total of 2863 articles. After removing 723 duplicated articles, the remaining 2140 articles were carefully screened by scanning titles and abstracts, which resulted in the exclusion of 1950 irrelevant studies. Afterwards 190 relevant studies were assessed for eligibility by scrutinizing full texts including figures and tables. 166 studies were excluded for the following reasons: 112 did not provide sufficient data, 22 were not digestive cancers, 1 was animal study, 24 were meeting abstracts and 7 were duplicated reports (Figure 1).

Finally, 24 cohort studies with 4141 patients were included in the cohort-based analysis, with a mean sample size of 172.5 (ranged from 76 to 690) [23, 24, 26-47]. Features of the 24 studies were listed in Table 1. The period of 24 studies ranged from 2011 to 2016. Among them, Kurahara et al. [34] reported prognostic value of ZEB1 and ZEB2 in pancreatic cancer within 1 article; Okugawa et al. provided prognostic value of ZEB1 [24] and ZEB2 [36] in gastric cancer in 2 articles, which originated from the same cohort; Xia et al. [42] used 2 independent cohort (cohort I and cohort II) to investigate whether ZEB2 expression could predict survival of patients with hepatocellular carcinoma. 11 studies were from China, 9 from Japan, 2 from German, 1 from America and 1 from Thailand. All studies used tissue specimens of patients, while the detection methods mainly focused on immunohistochemistry (IHC) and quantitative real time polymerase chain reaction (qRT-PCR). Types of cancer varied across studies, with 7 studies reported gastric cancer, 5 reported hepatocellular carcinoma, 4 reported colorectal cancer, 4 reported esophageal squamous cells carcinoma, 2 reported cholangiocarcinoma and 2 reported pancreatic cancer. The quality assessment was performed for each individual study according to the REMARK guideline and the results were shown in Table 2.

\section{High ZEB1 and ZEB2 levels predicted poor overall survival in digestive cancers}

The impact of tissue ZEB1 and ZEB2 expression on overall survival (OS) was investigated respectively. 14 studies reported the OS of 1855 patients according to ZEB1 expression and 10 studies reported the OS of 2215 patients according to ZEB2 expression. The heterogeneity test revealed that there was no significant heterogeneity in the 14 studies for ZEB1 $\left(\mathrm{I}^{2}=45.4 \%, p=0.033\right)$, while significant heterogeneity existed in the 10 studies for ZEB2 $\left(\mathrm{I}^{2}=52.6 \%, p=0.025\right)$. Therefore we adopted the fixed-effect model and the random-effect model for ZEB1 and ZEB2 respectively. As shown in Figure 2A and Figure $2 \mathrm{C}$, pooled analyses showed that elevated ZEB1 expression predicted unfavorable OS in digestive cancer patients (pooled HR: 1.610, 95\% CI: 1.412-1.835, $p<0.001$ ), so did ZEB2 (pooled HR: $1.543,95 \%$ CI: 1.288 $1.848, p<0.001$ ). Begg's funnel plot and Egger's test were carried to assess potential publication bias. The Begg's funnel plots were symmetrical, indicating that there was no significant publication bias, with $p_{\text {Begg }}=0.743$ and $p_{\text {Egger }}=0.556$ for ZEB1 (Figure 2B) and $p_{\text {Begg }}=0.474$ and $p_{\text {Egger }}=0.142$ for ZEB2 (Figure 2D). 


\section{Sensitivity analyses, subgroup analyses and cumulative meta-analysis}

Sensitivity analyses were performed by sequentially omitting single study to assess the stability of the pooled results. As shown in Figure $3 \mathrm{~A}$ and Figure 3B, no individual study changed pooled HR significantly.

We further performed subgroup analyses according to cancer type, country of origin, protein/mRNA, quality assessment score and sample size (Table 3). ZEB1 was found to be significantly associated with poor OS for patients with pancreatic cancer (pooled HR: 1.487, 95\% CI: 1.071-2.064, $p=0.018$ ), gastric cancer (pooled HR: 1.990, 95\% CI: $1.540-2.573, p<0.001)$ and colorectal cancer (pooled HR: 1.961, 95\% CI: 1.468-2.619, $p<0.001$ ), while ZEB2 was found to be significantly associated with poor OS for patients with hepatocellular carcinoma (pooled HR: 1.315, 95\% CI: 1.033-1.674, $p=0.026$ ) and gastric cancer (pooled HR: 2.063, 95\% CI: 1.582-2.691, $p<0.001)$. However, ZEB1 did not predict poor OS for patients with esophageal squamous cell carcinoma (pooled HR: 1.338, 95\% CI: 0.965-1.854, $p=0.081$ ) and hepatocellular carcinoma (pooled HR: 1.364, 95\% CI: $0.989-1.881, p=0.059$ ). Subgroup analyses aiming at other cancer types could not be conducted due to the limited study number.
Since most of the studies were conducted in China or Japan, we also stratified studies depending on the country of origin. We detected a significant association between ZEB family member expression and poor OS for patients with digestive cancers in China (pooled HR for ZEB1: 1.926, 95\% CI: 1.547-2.399, $p<0.001$; pooled HR for ZEB2: $1.493,95 \%$ CI: $1.180-1.889, p=0.001$ ) or Japan (pooled HR for ZEB1: 1.443, 95\% CI: 1.002-2.078, $p=0.049$; pooled HR for ZEB2: $1.986,95 \%$ CI: 1.453 $2.714, p<0.001)$. In addition, we further investigated whether protein and mRNA of ZEB family had the same prognostic value in digestive cancers. We found high ZEB1 and ZEB2 protein was associated with poor OS consistently (pooled HR for ZEB1: $1.488,95 \%$ CI: 1.194-1.854, $p<0.001$; pooled HR for ZEB2: $1.500,95 \%$ CI: 1.247-1.805, $p<0.001)$, however high ZEB1 mRNA predicted poor OS while high ZEB2 did not show the same effect, even though it had the tendency (pooled HR for ZEB1: 2.013 , 95\% CI: 1.563-2.592, $p<0.001$; pooled HR for ZEB2: $1.630,95 \%$ CI: 0.924-2.875, $p=0.092$ ). We divided studies into high quality group and low quality group according to quality assessment score (high quality group: score $>=15$; low quality group: score $<15$ ). Both ZEB1 and ZEB2 predicted unfavorable OS in high quality group (pooled HR for ZEB1: 1.693, 95\% CI: 1.290-2.222, $p<0.001$; pooled HR for ZEB2: $1.472,95 \%$ CI: $1.142-$

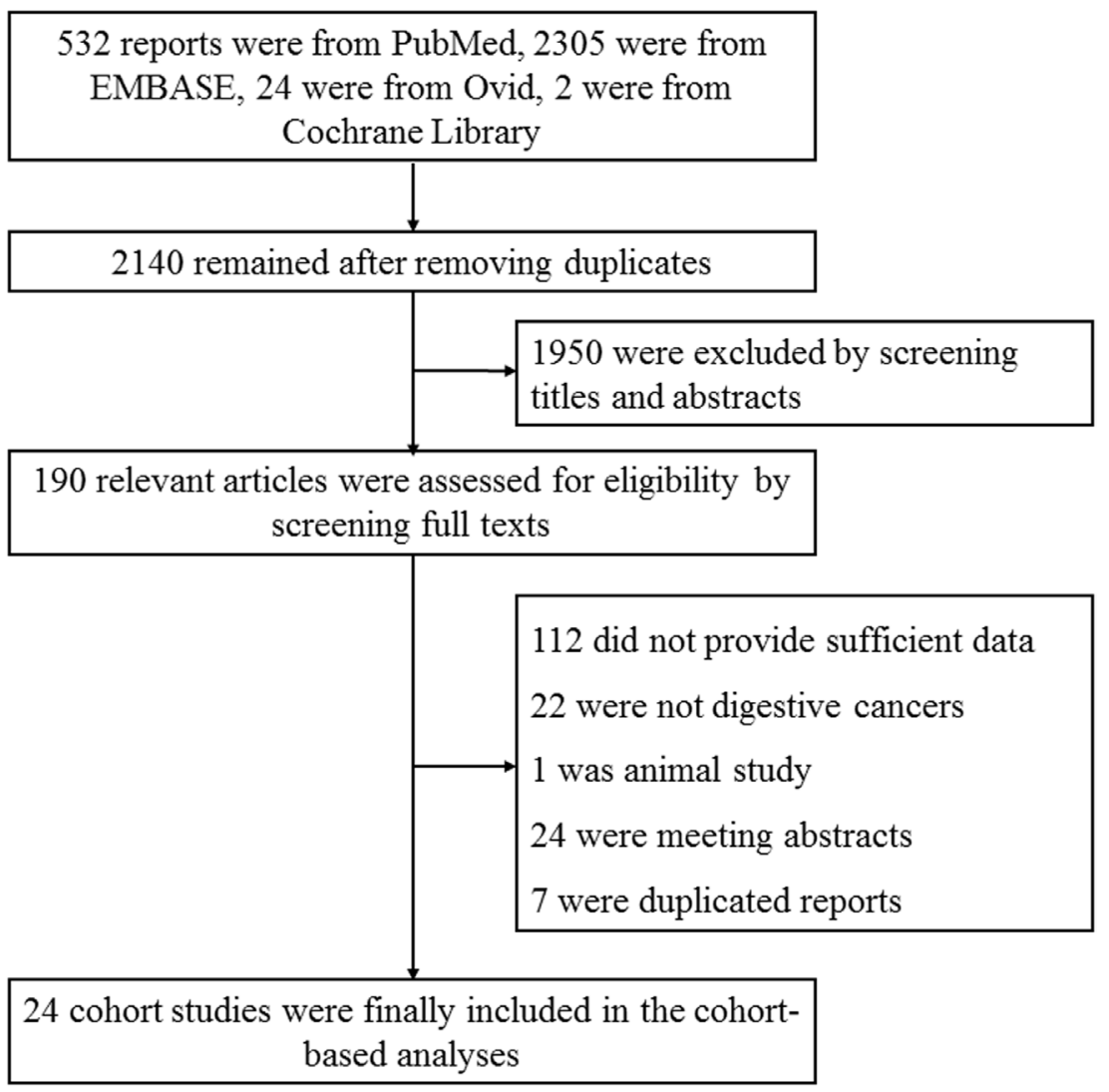

Figure 1: Flow diagram of the study selection process. 
Table 1A: Characteristics of the included studies (ZEB1)

\begin{tabular}{|c|c|c|c|c|c|c|c|c|c|c|c|}
\hline $\begin{array}{l}\text { Study } \\
\text { (year) }\end{array}$ & Country & Participants & $\begin{array}{l}\text { Follow-up } \\
\text { (month) }\end{array}$ & Age & Specimens & Method & $\begin{array}{l}\text { Protein/ } \\
\text { mRNA }\end{array}$ & Analysis & Endpoints & Cancer Type & $\begin{array}{c}\text { Quality } \\
\text { Assessment }\end{array}$ \\
\hline $\begin{array}{l}\text { Bronsert } \\
(2014)\end{array}$ & German & $59 / 58(\mathrm{M} / \mathrm{F})$ & NA & $\begin{array}{c}67 \\
\text { (median) }\end{array}$ & tissue & $\mathrm{IHC}$ & protein & multivariable & OS & pancreatic cancer & 14 \\
\hline $\begin{array}{l}\text { Goscinski } \\
(2015)\end{array}$ & China & $92 / 59(\mathrm{M} / \mathrm{F})$ & NA & $33-73$ & tissue & $\mathrm{IHC}$ & protein & univariable & OS & $\begin{array}{l}\text { esophageal squamous } \\
\text { cell carcinoma }\end{array}$ & 12 \\
\hline $\begin{array}{l}\text { Hara } \\
(2014)\end{array}$ & Japan & $79 / 14(\mathrm{M} / \mathrm{F})$ & $\begin{array}{c}46 \\
\text { (median) }\end{array}$ & $\begin{array}{c}64 \\
\text { (mean) }\end{array}$ & tissue & $\mathrm{IHC}$ & protein & univariable & OS & $\begin{array}{l}\text { esophageal squamous } \\
\text { cell carcinoma }\end{array}$ & 14 \\
\hline $\begin{array}{l}\text { Hashiguchi } \\
\text { (2013) }\end{array}$ & Japan & $85 / 23(\mathrm{M} / \mathrm{F})$ & $\begin{array}{c}48.4 \\
\text { (median) }\end{array}$ & $\begin{array}{c}65.3 \\
\text { (mean) }\end{array}$ & tissue & $\mathrm{IHC}$ & protein & multivariable & OS & $\begin{array}{l}\text { hepatocellular } \\
\text { carcinoma }\end{array}$ & 16 \\
\hline $\begin{array}{l}\text { Kurahara } \\
(2012)\end{array}$ & Japan & $52 / 24(\mathrm{M} / \mathrm{F})$ & NA & $\begin{array}{c}67 \\
\text { (median) }\end{array}$ & tissue & $\mathrm{IHC}$ & protein & univariable & OS & pancreatic cancer & 13 \\
\hline $\begin{array}{l}\text { Murai } \\
(2014)\end{array}$ & Japan & $83 / 33(\mathrm{M} / \mathrm{F})$ & $\begin{array}{c}37 \\
\text { (median) }\end{array}$ & $\begin{array}{c}64 \\
\text { (mean) }\end{array}$ & tissue & $\begin{array}{l}\text { qRT- } \\
\text { PCR }\end{array}$ & mRNA & univariable & OS & gastric cancer & 16 \\
\hline $\begin{array}{l}\text { Okugawa } \\
(2012)\end{array}$ & Japan & $\begin{array}{c}106 / 28 \\
(\mathrm{M} / \mathrm{F})\end{array}$ & $\begin{array}{c}23 \\
\text { (median) }\end{array}$ & $\begin{array}{c}67 \\
\text { (mean) }\end{array}$ & tissue & $\begin{array}{l}\text { qRT- } \\
\text { PCR }\end{array}$ & mRNA & multivariable & OS & gastric cancer & 14 \\
\hline $\begin{array}{l}\text { Singh } \\
(2011)\end{array}$ & America & $\begin{array}{c}136 / 114 \\
(\mathrm{M} / \mathrm{F})\end{array}$ & $0.4-142.6$ & $\begin{array}{c}64.6 \\
\text { (mean) }\end{array}$ & tissue & $\begin{array}{l}\text { gene } \\
\text { chip }\end{array}$ & mRNA & univariable & OS & colonrectal cancer & 9 \\
\hline $\begin{array}{l}\text { Terashita } \\
(2016)\end{array}$ & Japan & $63 / 39(\mathrm{M} / \mathrm{F})$ & $\begin{array}{c}35 \\
\text { (median) }\end{array}$ & NA & tissue & $\mathrm{IHC}$ & protein & multivariable & OS & cholangiocarcinoma & 16 \\
\hline Wu (2016) & China & 145 (total) & $\begin{array}{c}47.7 \\
\text { (median) }\end{array}$ & NA & tissue & IHC & protein & multivariable & OS, RFS & colonrectal cancer & 17 \\
\hline $\begin{array}{l}\text { Yang X. } \\
(2014)\end{array}$ & China & $68 / 32(\mathrm{M} / \mathrm{F})$ & $\begin{array}{c}32 \\
\text { (median) }\end{array}$ & $\begin{array}{c}50 \\
\text { (median) }\end{array}$ & tissue & $\mathrm{IHC}$ & protein & univariable & OS & $\begin{array}{l}\text { esophageal squamous } \\
\text { cell carcinoma }\end{array}$ & 16 \\
\hline $\begin{array}{l}\text { Zhang } \\
(2013)\end{array}$ & China & $50 / 42(\mathrm{M} / \mathrm{F})$ & NA & $\begin{array}{c}62 \\
\text { (mean) }\end{array}$ & tissue & $\begin{array}{l}\text { qRT- } \\
\text { PCR }\end{array}$ & mRNA & multivariable & OS & colonrectal cancer & 16 \\
\hline $\begin{array}{l}\text { Zhou L. } \\
\text { (2016) }\end{array}$ & China & $\begin{array}{c}172 / 89 \\
(\mathrm{M} / \mathrm{F})\end{array}$ & $8-110$ & NA & tissue & $\mathrm{IHC}$ & protein & multivariable & OS & gastric cancer & 16 \\
\hline $\begin{array}{l}\text { Zhou Y. } \\
\text { (2012) }\end{array}$ & China & $98 / 12(\mathrm{M} / \mathrm{F})$ & NA & $\begin{array}{c}54 \\
\text { (median) }\end{array}$ & tissue & $\begin{array}{c}\text { western } \\
\text { blot }\end{array}$ & protein & multivariable & OS, DFS & $\begin{array}{c}\text { hepatocellular } \\
\text { carcinoma }\end{array}$ & 13 \\
\hline
\end{tabular}

M: male; F: female; NA: not available; IHC: immunohistochemistry; qRT-PCR: quantitative real time polymerase chain reaction; OS: overall survival; RFS: recurrence free survival; DFS: disease free survival.

Table 1B: Characteristics of the included studies (ZEB2)

\begin{tabular}{|c|c|c|c|c|c|c|c|c|c|c|c|}
\hline $\begin{array}{l}\text { Study } \\
\text { (year) }\end{array}$ & Country & Participants & $\begin{array}{c}\text { Follow-up } \\
\text { (month) }\end{array}$ & Age & Specimens & Method & $\begin{array}{l}\text { Protein/ } \\
\text { mRNA }\end{array}$ & Analysis & Endpoints & Cancer Type & $\begin{array}{c}\text { Quality } \\
\text { Assessment }\end{array}$ \\
\hline Cai (2012) & China & $\begin{array}{c}220 / 28 \\
(\mathrm{M} / \mathrm{F})\end{array}$ & $\begin{array}{c}26.0 \\
\text { (median) }\end{array}$ & $\begin{array}{c}47.8 \\
\text { (mean) }\end{array}$ & tissue & $\mathrm{IHC}$ & protein & multivariabe & OS & $\begin{array}{l}\text { hepatocellular } \\
\text { carcinoma }\end{array}$ & 17 \\
\hline Dai (2012) & China & $50 / 26(\mathrm{M} / \mathrm{F})$ & $\begin{array}{c}40 \\
\text { (median) }\end{array}$ & $\begin{array}{c}53.8 \\
\text { (mean) }\end{array}$ & tissue & $\mathrm{IHC}$ & protein & Univariable & OS & gastric cancer & 14 \\
\hline $\begin{array}{l}\text { Kahlert } \\
(2011)\end{array}$ & German & $\begin{array}{c}121 / 54 \\
(\mathrm{M} / \mathrm{F})\end{array}$ & $\begin{array}{c}124 \\
\text { (median) }\end{array}$ & NA & tissue & $\mathrm{IHC}$ & protein & multivariabe & DFS & colorectal cancer & 14 \\
\hline $\begin{array}{l}\text { Kurahara } \\
(2012)\end{array}$ & Japan & $52 / 24(\mathrm{M} / \mathrm{F})$ & NA & $\begin{array}{c}67 \\
\text { (median) }\end{array}$ & tissue & $\mathrm{IHC}$ & protein & univariable & OS & pancreatic cancer & 13 \\
\hline $\begin{array}{l}\text { Okugawa } \\
(2013)\end{array}$ & Japan & $\begin{array}{c}106 / 28 \\
(\mathrm{M} / \mathrm{F})\end{array}$ & $\begin{array}{c}23 \\
\text { (median) }\end{array}$ & $\begin{array}{c}67 \\
\text { (mean) }\end{array}$ & tissue & $\begin{array}{l}\text { qRT- } \\
\text { PCR }\end{array}$ & mRNA & multivariabe & OS & gastric cancer & 15 \\
\hline $\begin{array}{l}\text { Otsuki } \\
(2011)\end{array}$ & Japan & $84 / 22(\mathrm{M} / \mathrm{F})$ & $\begin{array}{c}48 \\
\text { (median) }\end{array}$ & NA & tissue & $\begin{array}{l}\text { qRT- } \\
\text { PCR }\end{array}$ & mRNA & univariable & DFS, RFS & gastric cancer & 15 \\
\hline Sun (2015) & Chian & $\begin{array}{c}192 / 69 \\
(\mathrm{M} / \mathrm{F})\end{array}$ & $\begin{array}{c}50 \\
\text { (median) }\end{array}$ & $\begin{array}{c}59 \\
(\text { mean })\end{array}$ & tissue & $\mathrm{IHC}$ & protein & univariable & OS, DFS & gastric cancer & 17 \\
\hline
\end{tabular}




\begin{tabular}{|c|c|c|c|c|c|c|c|c|c|c|c|}
\hline $\begin{array}{l}\text { Study } \\
\text { (year) }\end{array}$ & Country & Participants & $\begin{array}{l}\text { Follow-up } \\
\text { (month) }\end{array}$ & Age & Specimens & Method & $\begin{array}{c}\text { Protein/ } \\
\text { mRNA }\end{array}$ & Analysis & Endpoints & Cancer Type & $\begin{array}{c}\text { Quality } \\
\text { Assessment }\end{array}$ \\
\hline $\begin{array}{l}\text { Techasen } \\
(2014)\end{array}$ & Thailand & $\begin{array}{l}149 / 66 \\
(\mathrm{M} / \mathrm{F})\end{array}$ & NA & $21-82$ & tissue & $\begin{array}{l}\text { IHC, } \\
\text { qRT- } \\
\text { PCR }\end{array}$ & $\begin{array}{l}\text { protein, } \\
\text { mRNA }\end{array}$ & univariable & OS & cholangiocarcinoma & 13 \\
\hline $\begin{array}{l}\text { Xia-cohort } \\
\text { I (2014) }\end{array}$ & China & $\begin{array}{c}581 / 109 \\
(\mathrm{M} / \mathrm{F})\end{array}$ & $4-96$ & $\begin{array}{c}51.8 \\
(\text { mean })\end{array}$ & tissue & $\mathrm{IHC}$ & protein & univariable & OS & $\begin{array}{l}\text { hepatocellular } \\
\text { carcinoma }\end{array}$ & 15 \\
\hline $\begin{array}{l}\text { Xia-cohort } \\
\text { II (2014) }\end{array}$ & China & $\begin{array}{l}256 / 56 \\
(\mathrm{M} / \mathrm{F})\end{array}$ & $4-96$ & $\begin{array}{c}51.9 \\
(\text { mean) }\end{array}$ & tissue & $\mathrm{IHC}$ & protein & univariable & OS & $\begin{array}{l}\text { hepatocellular } \\
\text { carcinoma }\end{array}$ & 15 \\
\hline $\begin{array}{l}\text { Yang Z. } \\
\text { (2015) }\end{array}$ & China & $79 / 13(\mathrm{M} / \mathrm{F})$ & NA & NA & tissue & $\mathrm{IHC}$ & protein & univariable & OS & $\begin{array}{l}\text { hepatocellular } \\
\text { carcinoma }\end{array}$ & 11 \\
\hline $\begin{array}{l}\text { Yoshida } \\
(2015)\end{array}$ & Japan & $\begin{array}{l}100 / 11 \\
(\mathrm{M} / \mathrm{F})\end{array}$ & NA & $\begin{array}{c}64.3 \\
\text { (mean) }\end{array}$ & tissue & $\mathrm{IHC}$ & protein & univariable & OS, DFS & $\begin{array}{l}\text { esophageal squamous } \\
\text { cell carcinoma }\end{array}$ & 12 \\
\hline
\end{tabular}

M: male; F: female; NA: not available; IHC: immunohistochemistry; qRT-PCR: quantitative real time polymerase chain reaction; OS: overall survival; RFS: recurrence free survival; DFS: disease free survival.

$1.898, p=0.003$ ) and low quality group (pooled HR for ZEB1: $1.586,95 \%$ CI: 1.196-2.104, $p=0.001$; pooled HR for ZEB2: $1.668,95 \%$ CI: 1.246-2.234, $p=0.001$ ).

To be noticed, when performing subgroup analyses stratified by sample size, we detected that ZEB1 and ZEB2 was significantly associated with poor OS in large sample size group (pooled HR for ZEB1: 1.702, 95\% CI: 1.394-2.078, $p<0.001$; pooled HR for ZEB2: $1.478,95 \%$ CI: 1.194-1.829, $p<0.001$ ), while ZEB1 failed to achieve statistical significance in small sample size group (pooled HR for ZEB1: $1.397,95 \%$ CI: $0.820-2.379, p=0.218$; pooled HR for ZEB2: 1.840 , 95\% CI: 1.324-2.555, $p<0.001)$. Therefore we further performed cumulative meta-analysis by sorting of the included studies according to the sample size. In accordance with subgroup analyses, we observed that statistical significance was reached after including large sample size studies (sample size $>=100$ ) for ZEB1, while the pooled HR has already met statistical significance since including small sample size studies (sample size < 100) for ZEB2, as shown in Figure 3C and Figure 3D. This finding implied that including studies with large sample size in the meta-analysis contributed to more stable results.

\section{Secondary analyses confirmed prognostic significance of ZEB1 and ZEB2 for patients with gastric cancer}

Since pooling studies with small sample size might bring about unstable results, secondary analyses utilizing time-to-event patient data were carried out to enlarge sample size. We only performed secondary analyses in gastric cancer, because only in gastric cancer did both ZEB1 and ZEB2 have significant prognostic value, and studies concerning gastric cancer provided adequate data for secondary analyses. Guyot's method was used to acquire time-to-event patient data from Kaplan-Meier survival curves. Survival curves of 3 studies from Murai
[35], Okugawa [24] and Zhou L. [46] were extracted for ZEB1, and survival curves of 3 studies from Dai [29], Okugawa [36] and Sun [38] were extracted for ZEB2, respectively. The reconstructed survival curves were displayed in Figure 4A and Figure 4B, which confirmed prognostic significance of ZEB1 and ZEB2 for patients with gastric cancer (HR for ZEB1: 2.305, 95\% CI: 2.1133.465 , log-rank $p<0.001$; HR for ZEB2: $1.927,95 \% \mathrm{CI}$ : $1.416-2.382$, log-rank $p<0.001$ ).

\section{High ZEB2 level predicted disease free survival in digestive cancers}

The impact of tissue ZEB2 expression on disease free survival (DFS) in digestive cancers was also investigated, whereas only Zhou Y. et al. [47] reported the association between tissue ZEB1 expression and DFS so it could not be performed. The heterogeneity test revealed that there was no significant heterogeneity between studies $\left(\mathrm{I}^{2}=34.5 \%, p=0.205\right)$. The fixed effect model was adopted and the pooled analyses showed that elevated ZEB2 expression predicted poor DFS in digestive cancer patients (pooled HR: 1.726, 95\% CI: 1.336-2.230, $p<0.001$ ), as shown in Figure 5A. The Begg's funnel plots were symmetrical (Figure 5B), indicating that there was no significant publication bias, with $p_{\text {Begg }}=0.734$ and $p_{\text {Egger }}=0.554$. We did not perform further subgroup analyses due to the limited study number.

\section{The association between increased ZEB family expression and clinicopathological features in digestive cancer patients}

The above results have demonstrated the prognostic significance of ZEB family, and we further investigated the association between increased ZEB family expression and clinicopathological features in digestive cancer patients. From the 24 included cohort studies, there were 16 studies 
Table 2A: Quality assessment according to the REMARK guideline (ZEB1)

\begin{tabular}{|c|c|c|c|c|c|c|c|c|c|c|c|c|c|c|c|c|c|c|c|c|c|}
\hline Study & Q1 & Q2 & Q3 & Q4 & Q5 & Q6 & Q7 & Q8 & Q9 & Q10 & Q11 & Q12 & Q13 & Q14 & Q15 & Q16 & Q17 & Q18 & Q19 & Q20 & Total \\
\hline Bronsert (2014) & 1 & 1 & 1 & 1 & 1 & 1 & 0 & 0 & 0 & 1 & 1 & 1 & 1 & 0 & 1 & 0 & 0 & 1 & 1 & 1 & 14 \\
\hline $\begin{array}{l}\text { Goscinski } \\
\text { (2015) }\end{array}$ & 1 & 1 & 1 & 1 & 1 & 0 & 0 & 0 & 0 & 1 & 1 & 0 & 0 & 1 & 1 & 0 & 0 & 1 & 1 & 1 & 12 \\
\hline Hara (2014) & 1 & 1 & 1 & 1 & 1 & 1 & 0 & 1 & 0 & 1 & 1 & 0 & 0 & 0 & 1 & 1 & 0 & 1 & 1 & 1 & 14 \\
\hline $\begin{array}{l}\text { Hashiguchi } \\
\text { (2013) }\end{array}$ & 1 & 1 & 1 & 1 & 1 & 1 & 0 & 0 & 0 & 1 & 1 & 0 & 1 & 1 & 1 & 1 & 1 & 1 & 1 & 1 & 16 \\
\hline Kurahara (2012) & 1 & 1 & 1 & 1 & 1 & 0 & 0 & 0 & 0 & 1 & 1 & 0 & 1 & 1 & 1 & 0 & 0 & 1 & 1 & 1 & 13 \\
\hline Murai (2014) & 1 & 1 & 1 & 1 & 1 & 1 & 0 & 0 & 0 & 1 & 1 & 0 & 1 & 1 & 1 & 1 & 1 & 1 & 1 & 1 & 16 \\
\hline Okugawa (2012) & 1 & 1 & 1 & 1 & 1 & 1 & 0 & 1 & 0 & 1 & 0 & 0 & 1 & 0 & 1 & 1 & 0 & 1 & 1 & 1 & 14 \\
\hline Singh (2011) & 1 & 1 & 1 & 1 & 1 & 0 & 0 & 0 & 0 & 1 & 0 & 0 & 0 & 0 & 0 & 0 & 0 & 1 & 1 & 1 & 9 \\
\hline Terashita (2016) & 1 & 1 & 1 & 1 & 1 & 1 & 0 & 1 & 0 & 1 & 1 & 0 & 1 & 1 & 0 & 1 & 1 & 1 & 1 & 1 & 16 \\
\hline Wu (2016) & 1 & 1 & 1 & 1 & 1 & 1 & 1 & 1 & 0 & 1 & 1 & 0 & 0 & 1 & 1 & 1 & 1 & 1 & 1 & 1 & 17 \\
\hline Yang X. (2014) & 1 & 1 & 1 & 1 & 1 & 1 & 1 & 1 & 0 & 1 & 1 & 0 & 1 & 1 & 1 & 0 & 0 & 1 & 1 & 1 & 16 \\
\hline Zhang (2013) & 1 & 1 & 1 & 1 & 1 & 0 & 0 & 1 & 0 & 1 & 1 & 0 & 1 & 1 & 1 & 1 & 1 & 1 & 1 & 1 & 16 \\
\hline Zhou L. (2016) & 1 & 1 & 1 & 1 & 1 & 1 & 1 & 1 & 0 & 1 & 1 & 0 & 1 & 1 & 0 & 1 & 0 & 1 & 1 & 1 & 16 \\
\hline Zhou Y. (2012) & 1 & 1 & 1 & 1 & 1 & 0 & 0 & 0 & 0 & 1 & 1 & 0 & 1 & 1 & 0 & 1 & 0 & 1 & 1 & 1 & 13 \\
\hline
\end{tabular}

Table 2B: Quality assessment according to the REMARK guideline (ZEB2)

\begin{tabular}{llllllllllllllll}
\hline Study & Q1 & Q2 & Q3 & Q4 & Q5 & Q6 & Q7 & Q8 & Q9 & Q10 & Q11 & Q12 & Q13 & Q14 Q15 Q16 Q17 Q18 Q19 Q20 Total
\end{tabular}

Cai (2012)

Dai (2012)

$\begin{array}{llllllllllllllllllllll}\text { Kahlert (2011) } & 1 & 1 & 1 & 1 & 1 & 1 & 0 & 1 & 0 & 1 & 1 & 0 & 0 & 0 & 1 & 1 & 0 & 1 & 1 & 1 & 14\end{array}$

$\begin{array}{llllllllllllllllllllll}\text { Kurahara (2012) } & 1 & 1 & 1 & 1 & 1 & 0 & 0 & 0 & 0 & 1 & 1 & 0 & 1 & 1 & 1 & 0 & 0 & 1 & 1 & 1 & 13\end{array}$

$\begin{array}{llllllllllllllllllllll}\text { Okugawa (2013) } & 1 & 1 & 1 & 1 & 1 & 1 & 0 & 1 & 0 & 1 & 0 & 0 & 1 & 1 & 1 & 1 & 0 & 1 & 1 & 1 & 15\end{array}$

$\begin{array}{lllllllllllllllllllllll}\text { Otsuki (2011) } & 1 & 1 & 1 & 1 & 1 & 1 & 0 & 0 & 0 & 1 & 1 & 0 & 1 & 1 & 1 & 1 & 0 & 1 & 1 & 1 & 15\end{array}$

$\begin{array}{lllllllllllllllllllllll}\text { Sun (2015) } & 1 & 1 & 1 & 1 & 1 & 1 & 1 & 0 & 0 & 1 & 1 & 0 & 1 & 1 & 1 & 1 & 1 & 1 & 1 & 1 & 17\end{array}$

$\begin{array}{llllllllllllllllllllll}\text { Techasen (2014) } & 1 & 1 & 1 & 1 & 1 & 0 & 0 & 0 & 0 & 1 & 1 & 0 & 1 & 1 & 1 & 0 & 0 & 1 & 1 & 1 & 13\end{array}$

Xia-cohort I

(2014)

Xia-cohort II

(2014)

Yang Z. (2015)

$\begin{array}{llllllllllllllllllllll}\text { Yoshida (2015) } & 1 & 1 & 1 & 1 & 1 & 0 & 0 & 0 & 0 & 1 & 1 & 0 & 1 & 1 & 0 & 0 & 0 & 1 & 1 & 1 & 12\end{array}$

providing sufficient clinicopathological data of digestive cancer patients for analyses [26, 29, 32-35, 38-40, 43-47]. In addition to that, another 1 previous excluded non-cohort study was retrieved because it reported the relationship between ZEB1 expression in gastric cancer tissues and clinicopathological characteristics [48]. As shown in Table 4, we observed that high ZEB family expression were not associated with age (pooled OR for ZEB1: 0.741, 95\%
CI: 0.442-1.243, $p=0.256$; pooled OR for ZEB2: 1.155 , 95\% CI: $0.854-1.561, p=0.349$ ) or gender (pooled OR for ZEB1: 0.902, 95\% CI: 0.678-1.200, $p=0.479$; pooled OR for ZEB2: $1.010,95 \%$ CI: $0.746-1.369, p=0.948$ ). Interestingly, high ZEB1 expression was significantly associated with large tumor size (pooled OR for ZEB1: 1.571, 95\% CI: $1.162-2.124, p=0.003$; pooled OR for ZEB2: $1.318,95 \%$ CI: $0.888-1.956, p=0.171)$ and poor 
differentiation (pooled OR for ZEB1: 2.428, 95\% CI: 1.644-3.578, $p<0.001$; pooled OR for ZEB2: $1.068,95 \%$ CI: $0.159-7.146, p=0.946$ ), while ZEB2 did not show the same effect. What's more, both ZEB1 and ZEB2 were found to be significantly associated with depth of invasion (pooled OR for ZEB1: 2.423 , 95\% CI: 1.311 4.478, $p=0.005$; pooled OR for ZEB2: $2.187,95 \% \mathrm{CI}$ : 1.009-4.743, $p=0.047$ ), lymph node metastasis (pooled OR for ZEB1: 3.136, 95\% CI: 2.278-4.317, $p<0.001$; pooled OR for ZEB2: 2.360 , 95\% CI: $1.701-3.276, p<0.001)$ and TNM stage (pooled OR for ZEB1: 4.194, 95\% CI: 2.449-7.183, $p<0.001$; pooled OR for ZEB2: 3.169, 95\% CI: $2.079-4.830, p<0.001)$. There were significant heterogeneity between studies regarding age, depth of invasion and TNM stage for ZEB1, while differentiation and depth of invasion for ZEB2. However, further subgroup analyses were not applicable for the relationship between ZEB family expression and clinicopathological features of digestive cancer patients because of the limited number of studies. Besides, Begg's test and Egger's test both showed the absence of potential publication bias.

\section{DISCUSSION}

Identifying potential prognostic markers for digestive cancer patients is necessary as these markers will help provide valuable information for clinical scientists. In recent years, the association between ZEB family and patient clinical outcome has been reported in various cancers, despite that the results were inconsistent across studies [23-47]. We conducted this first cohort-based analysis and secondary analysis focusing on the prognostic value of ZEB family members in digestive cancers. Our
A

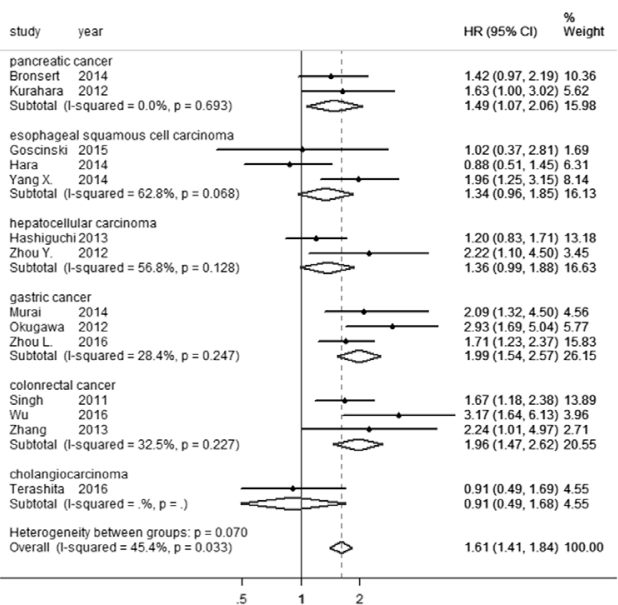

C

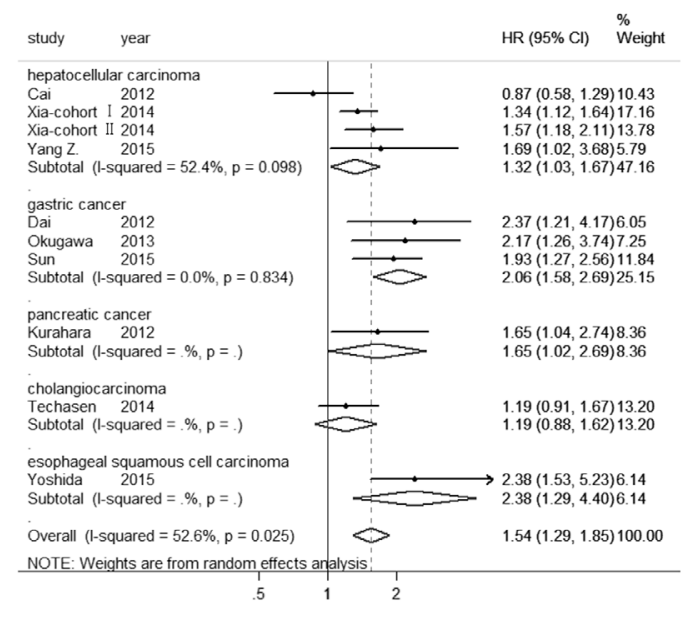

B

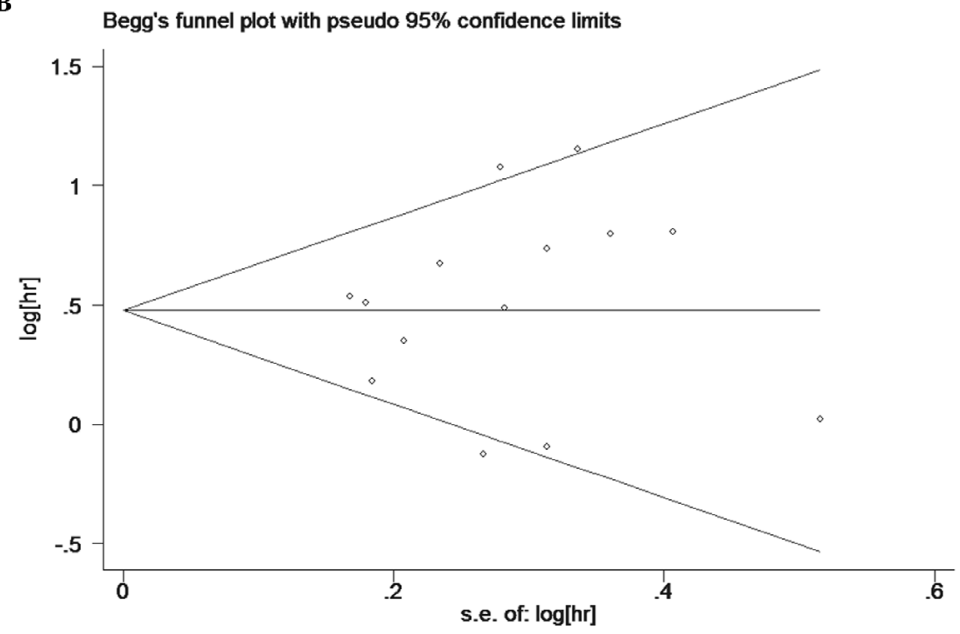

D

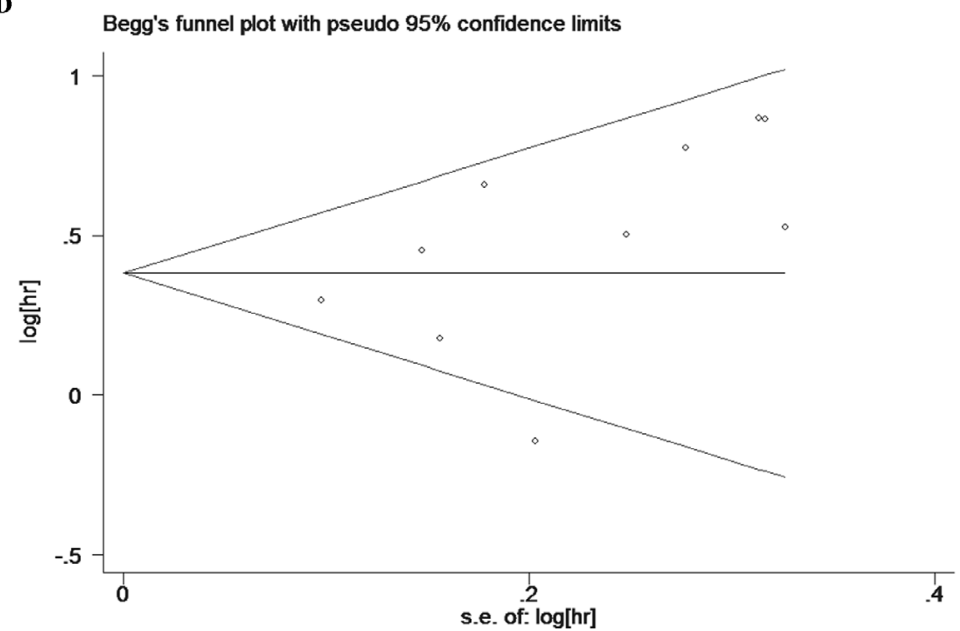

Figure 2: High ZEB1 and ZEB2 levels predicted poor overall survival in digestive cancers. A. Forest plot of HR for the association between ZEB1 expression and overall survival in patients with digestive cancers. B. Funnel plot for the association between ZEB1 expression and overall survival in patients with digestive cancers. C. Forest plot of HR for the association between ZEB2 expression and overall survival in patients with digestive cancers. D. Funnel plot for the association between ZEB2 expression and overall survival in patients with digestive cancers. 
results implied that both high ZEB1 and ZEB2 expression predicted poor OS in patients with digestive cancers. Specifically, ZEB1 was found to be significantly associated with poor OS for pancreatic cancer, gastric cancer and colorectal cancer patients, while ZEB2 was found to be significantly associated with poor OS for hepatocellular carcinoma and gastric cancer patients. The reconstructed survival curves utilizing time-to-event data confirmed the prognostic value of ZEB family in gastric cancer as well. In addition, we also observed ZEB2 expression predicted poor DFS in patients with digestive cancers. Finally, the results showed high ZEB1 expression was significantly associated with tumor size, differentiation, depth of invasion, lymph node metastasis and TNM stage, while high ZEB2 expression was significantly associated with depth of invasion, lymph node metastasis and TNM stage in digestive cancer patients.

Explanations for the prognostic value of ZEB family might require multiple mechanisms. First, classical theory that ZEB family members suppress E-cadherin expression and induce EMT is widely accepted [17, 19]; Second, ZEB family could form a complex regulatory network with p53 family members and their downstream targets,

A

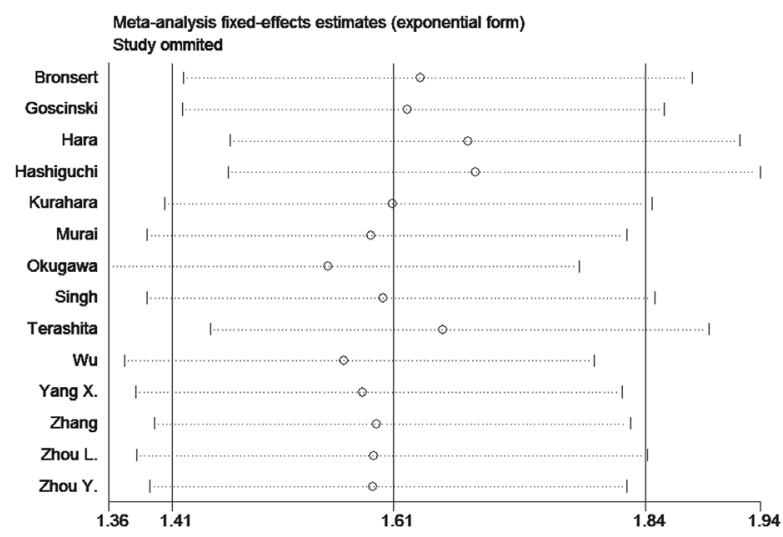

C

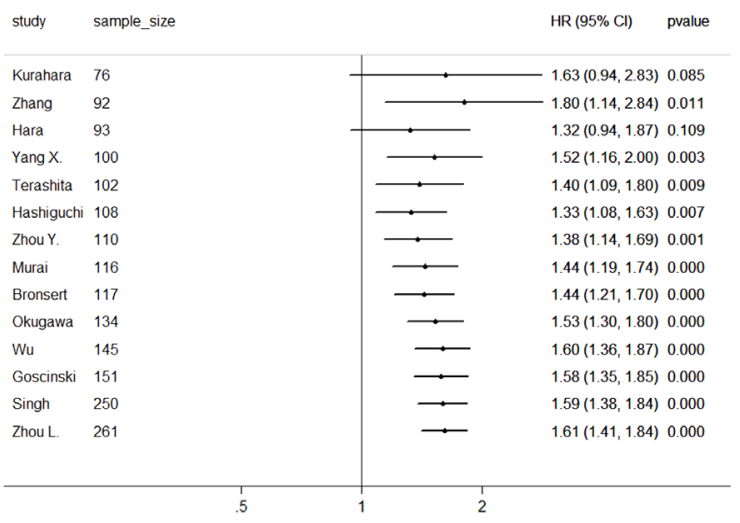

thus modulating cell cycle progression and apoptosis $[49,50]$. Besides, ZEB1 has been reported to help cancer cells develop resistance to radiation via stabilizing CHK1 [51], while ZEB2 could protect cancer cells from UV or cisplatin induced apoptosis [52]. Overall, digestive cancer patients with high expression of ZEB family tend to have metastatic tumors or acquire resistance to chemotherapy or radiotherapy, thus leading to poor survival outcomes.

We found that ZEB2 did not always have the same prognostic significance and clinicopathological association as ZEB1, especially when performing subgroup analyses according to cancer type. One possible interpretation is that ZEB family may have different expression profiles in various cancer tissues. Besides, different signaling pathways are involved and ZEB2 was reported to act as a tumor suppressor in some cancers via mediating the TGFbeta regulated repression of hTERT [53] and interacting with retinoblastoma pathway [54]. In the present study, we observed the prognostic value of ZEB family was most effective in gastric cancer, as verified by our secondary analyses as well. There are several reasons for that. First, Murai et al. [35] found that compared with epithelial status, mesenchymal status predicted poor OS in gastric

B

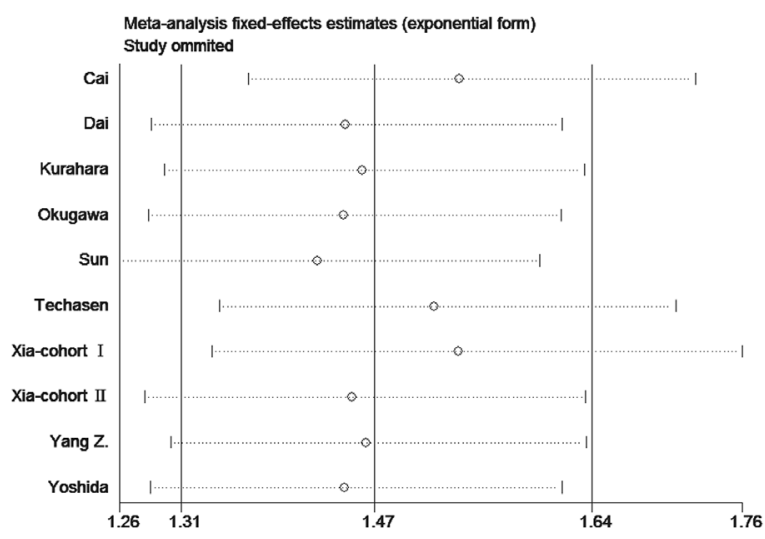

D

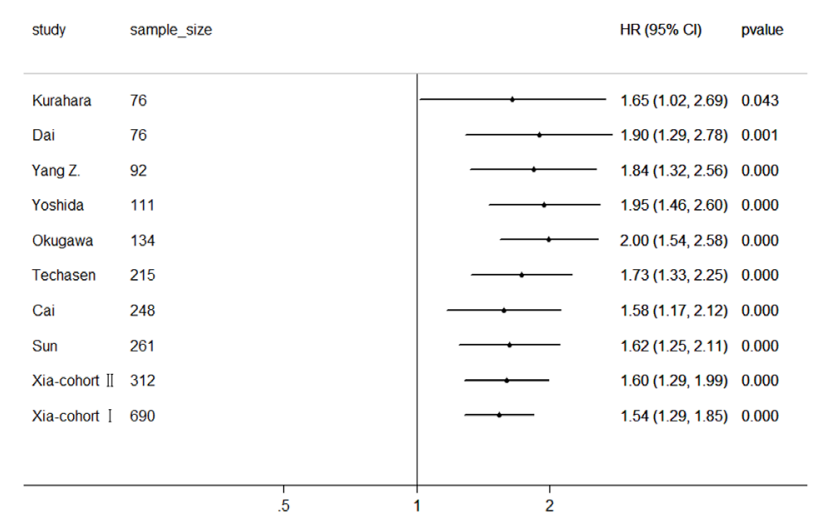

Figure 3: Sensitivity analyses by sequentially omitting single study for A. ZEB1 and B. ZEB2. Cumulative meta-analysis was performed according to sample size for C. ZEB1 and D. ZEB2, and the studies were added one at a time to pool the results sequentially. 
Table 3: Subgroup analyses

\begin{tabular}{|c|c|c|c|c|c|c|c|c|c|c|c|c|c|c|}
\hline & \multicolumn{7}{|c|}{ ZEB1 } & \multicolumn{7}{|c|}{ ZEB2 } \\
\hline & \multirow{2}{*}{$\begin{array}{l}\text { pooled } \\
\text { HR }\end{array}$} & \multirow{2}{*}{$95 \% \mathrm{CI}$} & \multirow{2}{*}{$p$} & \multicolumn{2}{|c|}{ heterogeneity } & \multirow{2}{*}{$p_{\text {Begg }}$} & \multirow{2}{*}{$p_{\text {Egger }}$} & \multirow{2}{*}{$\begin{array}{l}\text { pooled } \\
\text { HR }\end{array}$} & \multirow{2}{*}{$95 \% \mathrm{CI}$} & \multirow{2}{*}{$p$} & \multicolumn{2}{|c|}{ heterogeneity } & \multirow{2}{*}{$p_{\text {Begg }}$} & \multirow{2}{*}{$p_{\text {Egger }}$} \\
\hline & & & & $I^{2}(\%)$ & $p$ & & & & & & $I^{2}(\%)$ & $p$ & & \\
\hline \multicolumn{15}{|l|}{ cancer type } \\
\hline pancreatic cancer & 1.487 & $(1.071,2.064)$ & 0.018 & 0.0 & 0.693 & 1.000 & - & - & - & - & - & - & - & - \\
\hline $\begin{array}{l}\text { esophageal squamous } \\
\text { cell carcinoma }\end{array}$ & 1.338 & $(0.965,1.854)$ & 0.081 & 62.8 & 0.068 & 1.000 & 0.731 & - & - & - & - & - & - & - \\
\hline $\begin{array}{l}\text { hepatocellular } \\
\text { carcinoma }\end{array}$ & 1.364 & $(0.989,1.881)$ & 0.059 & 56.8 & 0.128 & 1.000 & - & 1.315 & $(1.033,1.674)$ & 0.026 & 52.4 & 0.098 & 1.000 & 0.886 \\
\hline gastric cancer & 1.990 & $(1.540,2.573)$ & $<0.001$ & 28.4 & 0.247 & 1.000 & 0.432 & 2.063 & $(1.582,2.691)$ & $<0.001$ & 0.0 & 0.834 & 0.296 & 0.093 \\
\hline colonrectal cancer & 1.961 & $(1.468,2.619)$ & $<0.001$ & 32.5 & 0.227 & 1.000 & 0.393 & - & - & - & - & - & - & - \\
\hline \multicolumn{15}{|l|}{ country } \\
\hline China & 1.926 & $(1.547,2.399)$ & $<0.001$ & 0.0 & 0.476 & 1.000 & 0.724 & 1.493 & $(1.180,1.889)$ & 0.001 & 60.2 & 0.028 & 1.000 & 0.551 \\
\hline Japan & 1.443 & $(1.002,2.078)$ & 0.049 & 65.6 & 0.013 & 1.000 & 0.601 & 1.986 & $(1.453,2.714)$ & $<0.001$ & 0.0 & 0.609 & 0.296 & 0.209 \\
\hline \multicolumn{15}{|l|}{ protein/mRNA } \\
\hline protein & 1.488 & $(1.194,1.854)$ & $<0.001$ & 46.1 & 0.054 & 0.858 & 0.929 & 1.500 & $(1.247,1.805)$ & $<0.001$ & 52.7 & 0.031 & 0.754 & 0.240 \\
\hline mRNA & 2.013 & $(1.563,2.592)$ & $<0.001$ & 0.0 & 0.392 & 0.734 & 0.345 & 1.630 & $(0.924,2.875)$ & 0.092 & 52.9 & 0.145 & 1.000 & - \\
\hline \multicolumn{15}{|l|}{ quality assessment } \\
\hline score $>=15$ & 1.693 & $(1.290,2.222)$ & $<0.001$ & 50.1 & 0.062 & 0.764 & 0.418 & 1.472 & $(1.142,1.898)$ & 0.003 & 66.7 & 0.017 & 0.806 & 0.693 \\
\hline score $<15$ & 1.586 & $(1.196,2.104)$ & 0.001 & 48.8 & 0.069 & 1.000 & 0.966 & 1.668 & $(1.246,2.234)$ & 0.001 & 39.7 & 0.156 & 0.806 & 0.023 \\
\hline \multicolumn{15}{|l|}{ sample size } \\
\hline large $(>=100)$ & 1.702 & $(1.394,2.078)$ & $<0.001$ & 43.8 & 0.059 & 0.640 & 0.535 & 1.478 & $(1.194,1.829)$ & $<0.001$ & 62.5 & 0.014 & 0.548 & 0.391 \\
\hline small (<100) & 1.397 & $(0.820,2.379)$ & 0.218 & 55.9 & 0.103 & 0.296 & 0.446 & 1.840 & $(1.324,2.555)$ & $<0.001$ & 0.0 & 0.636 & 1.000 & 0.635 \\
\hline
\end{tabular}

cancer, which made it logical and reasonable considering ZEB family's EMT promoting role. Furthermore, high ZEB1 expression was an independent indicator of peritoneal dissemination, which was responsible for the majority of mortality in gastric cancer patients [24]. Apart from ZEB family protein level, Yabusaki et al. [55] found that ZEB1 mRNA in peritoneal washing was associated with poor survival and clinicopathological features, which may account for that ZEB1 mRNA, but not ZEB2 mRNA, predicted poor OS for digestive cancer patients. Besides,
A

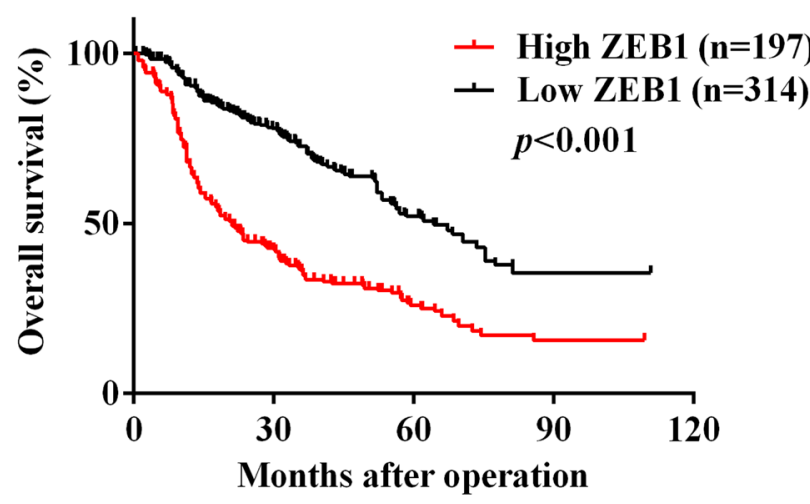

B

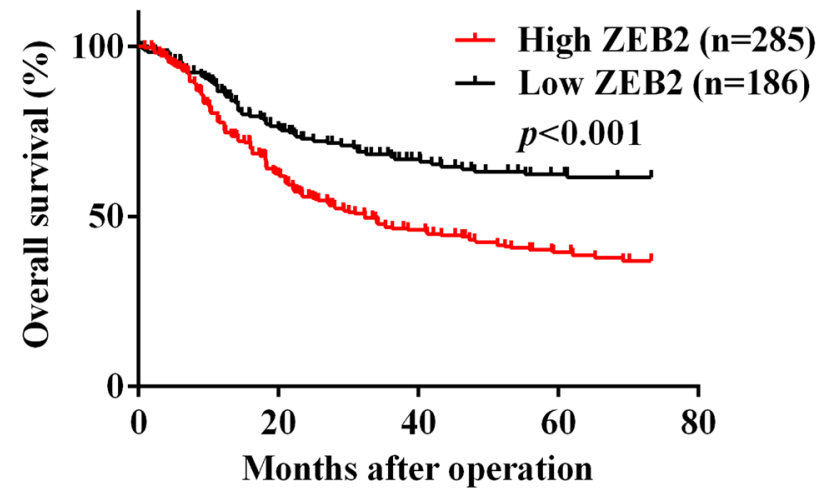

Figure 4: Reconstructed Kaplan Meier survival curves for overall survival of gastric cancer patients according to tissue A. ZEB1 and B. ZEB2 level. 
Table 4: Association between increased ZEB family expression and clinicopathological features in digestive cancer patients

\begin{tabular}{|c|c|c|c|c|c|c|c|c|c|c|c|c|c|c|}
\hline & \multicolumn{7}{|c|}{ ZEB1 } & \multicolumn{7}{|c|}{ ZEB2 } \\
\hline & \multirow{2}{*}{$\begin{array}{l}\text { pooled } \\
\text { OR }\end{array}$} & \multirow{2}{*}{$95 \% \mathrm{CI}$} & \multirow{2}{*}{$p$} & \multicolumn{2}{|c|}{ heterogeneity } & \multirow[b]{2}{*}{$p_{\text {Begg }}$} & \multirow{2}{*}{$p_{\text {Egger }}$} & \multirow{2}{*}{$\begin{array}{c}\text { pooled } \\
\text { OR }\end{array}$} & \multirow{2}{*}{$95 \% \mathrm{CI}$} & \multirow[b]{2}{*}{$p$} & \multicolumn{2}{|c|}{ heterogeneity } & \multirow[b]{2}{*}{$p_{\text {Begg }}$} & \multirow[b]{2}{*}{$p_{\text {Egger }}$} \\
\hline & & & & $I^{2}(\%)$ & $p$ & & & & & & $I^{2}(\%)$ & $p$ & & \\
\hline age (old vs young) ${ }^{1}$ & 0.741 & $(0.442,1.243)$ & 0.256 & 59.1 & 0.032 & 1.000 & 0.735 & 1.155 & $(0.854,1.561)$ & 0.349 & 44.5 & 0.125 & 0.806 & 0.619 \\
\hline gender (male vs female) & 0.902 & $(0.678,1.200)$ & 0.479 & 46.4 & 0.061 & 0.466 & 0.127 & 1.010 & $(0.746,1.369)$ & 0.948 & 0.0 & 0.631 & 1.000 & 0.715 \\
\hline $\begin{array}{l}\text { tumor size (large vs } \\
\text { small) })^{2}\end{array}$ & 1.571 & $(1.162,2.124)$ & 0.003 & 0.0 & 0.937 & 0.902 & 0.629 & 1.318 & $(0.888,1.956)$ & 0.171 & 0.0 & 0.712 & 1.000 & 0.616 \\
\hline $\begin{array}{l}\text { differentiation (poor vs } \\
\text { moderate+well) }\end{array}$ & 2.428 & $(1.644,3.578)$ & $<0.001$ & 22.9 & 0.268 & 0.806 & 0.617 & 1.068 & $(0.159,7.146)$ & 0.946 & 93.7 & $<0.001$ & 0.296 & 0.182 \\
\hline $\begin{array}{l}\text { depth of invasion } \\
(\mathrm{T} 3+\mathrm{T} 4 \text { vs } \mathrm{T} 1+\mathrm{T} 2 \text { or } \mathrm{T} 4 \\
\text { vs } \mathrm{T} 1+\mathrm{T} 2+\mathrm{T} 3)\end{array}$ & 2.423 & $(1.311,4.478)$ & 0.005 & 50.9 & 0.07 & 0.260 & 0.247 & 2.187 & $(1.009,4.743)$ & 0.047 & 61.0 & 0.053 & 1.000 & 0.646 \\
\hline $\begin{array}{l}\text { lymph node metastasis } \\
\text { (positive vs negative) }\end{array}$ & 3.136 & $(2.278,4.317)$ & $<0.001$ & 6.8 & 0.376 & 0.764 & 0.932 & 2.360 & $(1.701,3.276)$ & $<0.001$ & 28.4 & 0.232 & 0.462 & 0.021 \\
\hline $\begin{array}{l}\text { TNM stage (III+IV vs } \\
\mathrm{I}+\mathrm{II} \text { or IV vs I+II+III) }\end{array}$ & 4.194 & $(2.449,7.183)$ & $<0.001$ & 57.2 & 0.029 & 0.764 & 0.508 & 3.169 & $(2.079,4.830)$ & $<0.001$ & 0.0 & 0.610 & 1.000 & 0.094 \\
\hline
\end{tabular}

1: The cut-off value of age was various across studies.

2: Tumor size was measured according to diameter or volume across studies.

high ZEB2 expression was strongly associated with lactate dehydrogenase A (LDHA) expression in gastric cancer [38], and LDHA was a crucial enzyme in the final step of the Warburg effect, through which high rate of glycolysis was executed in cancer cells [56]. Still, further studies will be necessary to explore the molecular mechanisms and clinical significance of ZEB family in digestive cancers, especially in gastric cancer.

It is noteworthy that our study had numerous strengths. To our limited knowledge, we conducted a first systematic literature search and applied a scientific approach to comprehensively investigate the prognostic significance of ZEB family in digestive cancers. The included studies were all cohort studies of high methodological quality. Sensitivity analyses were performed to increase the stability and reliability of the pooled results, and we also further investigated the association between ZEB family and survival outcome in various subgroups. In addition, we performed secondary analyses adopting enlarged sample size to confirm the prognostic significance of ZEB family in gastric cancer. After validating the prognostic value of ZEB family, we further investigated the association between ZEB family expression and clinicopathological features in digestive cancer patients. The methods of this study were rigorous and were based on guidelines for conducting the present study.
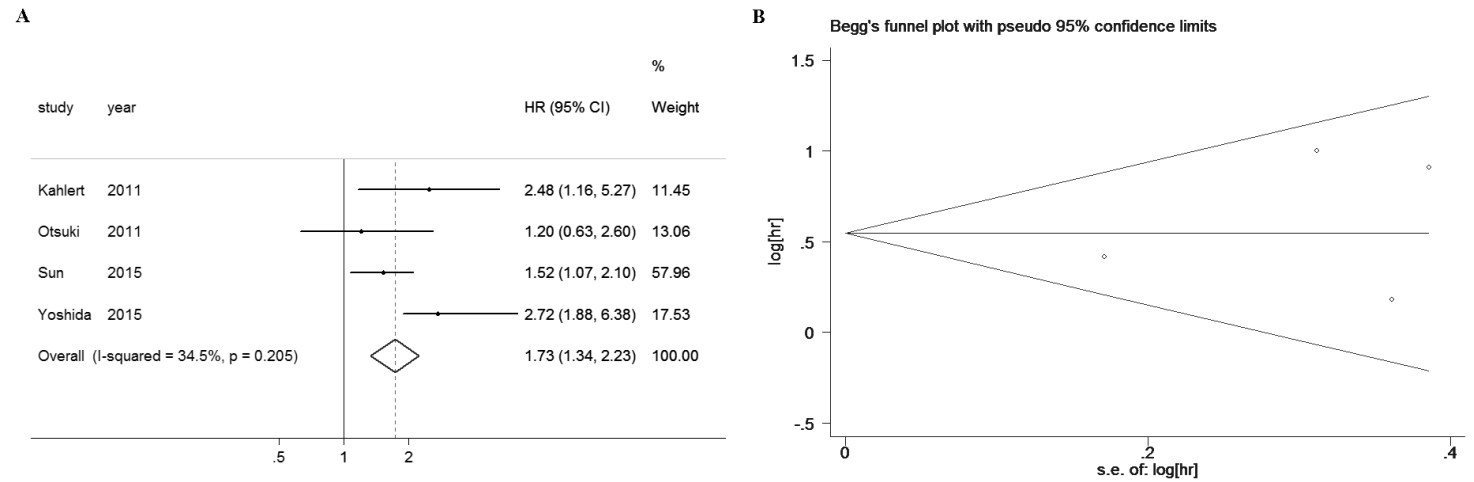

Figure 5: High ZEB2 levels predicted poor disease free survival in digestive cancers. A. Forest plot of $H R$ for the association between ZEB2 expression and disease free survival in patients with digestive cancers. B. Funnel plot for the association between ZEB2 expression and disease free survival in patients with digestive cancers. 
Still, this cohort-based analysis was limited in some aspects as well. First, the number of studies was relatively small thus sufficient subgroup analyses according to cancer type could not be performed. Second, we did not perform pooled analyses for the association between tissue ZEB1 expression and DFS because only 1 study reported it. Third, the majority of the studies were conducted in China or Japan, so the conclusions should be taken cautiously when applied for other ethnic populations. We suggested more cohort studies concerning a specific type of digestive cancer were needed to further identify the prognostic value of ZEB family and follow-up endpoints such as DFS or RFS should also be recorded. Although the incidences of some digestive cancers were relatively low in western countries, the ethnic composition of patients should be diverse. Finally, future cohort studies should recruit more patients to enlarge sample size, which will yield more stable and reliable results.

In conclusion, the present cohort-based analysis validated the prognostic value and clinicopathological association of ZEB family in digestive cancers, especially in gastric cancer.

\section{MATERIALS AND METHODS}

\section{Search strategy}

We performed a systematic literature search in four electronic databases: PubMed, EMBASE, Ovid and Cochrane Library. The search strategy was as follows: ((“ZEB1" OR “AREB6" OR "BZP” OR "DELTAEF1" OR "FECD6" OR "NIL2A" OR "PPCD3" OR "TCF8" OR "ZFHEP" OR "ZFHX1A") OR ("ZEB2" OR "HSPC082" OR "SIP-1" OR “SIP1” OR "SMADIP1” OR "ZFHX1B")) AND ("cancer" OR "tumor" OR "tumour" OR “carcinoma” OR "neoplasm” OR "neoplasia” OR "adenoma" OR "sarcoma"). The reference list of each study was also manually screened in order to retrieve potentially missing studies. The literature search procedure was conducted up to September, 2016. The present study was designed, conducted and reported according to the PRISMA statement [57], as shown in Supplementary Table 1 [58].

\section{Study selection criteria}

Two independent investigators (Wei Lu and Huihui Chen) carefully scrutinized the literatures from the initial search. Duplicated studies were first excluded, afterwards titles and abstracts were carefully skimmed, and finally full texts of potential qualified studies were reviewed. Studies were considered eligible and included if they meet the following criteria: (1) Studies were cohort studies whose patients had digestive cancers (pancreatic cancer, esophageal squamous cell carcinoma, hepatocellular carcinoma, gastric cancer, colorectal cancer, cholangiocarcinoma and hepatocellular carcinoma); (2) Expression levels of ZEB family members (ZEB1 or ZEB2) were detected in cancer tissues; (3) Studies described the association between ZEB1 or ZEB2 levels and survival outcome (overall survival or recurrence free survival or disease free survival); (4) Hazard ratio (HR) and its corresponding 95\% confidence interval (CI) were available or could be calculated; (5) For studies reporting duplicated or overlapping cohorts only the most complete studies were included. Studies were excluded if they meet the following criteria: (1) Studies were not original studies such as abstracts, reviews, expert opinions, editorials or case reports; (2) Studies were based on cancer cells or animals rather than patients; (3) Patients had other types of cancer beyond digestive system; (4) Studies did not report $\mathrm{HR}$ and its corresponding $95 \% \mathrm{CI}$ or they could not be calculated.

\section{Data extraction and quality assessment}

Data extraction was conducted by two independent investigators (Wei Lu and Huihui Chen) from texts, figures and tables. The following information was extracted: first authors, year of publication, country of origin, number of patients, follow-up duration, age, specimen types, detection methods, protein/mRNA, analysis methods, endpoints, cancer types. The definitions of ZEB1 or ZEB2 high expression group were in accordance with each original study. For studies which only provided survival data in Kaplan-Meier survival curves, the software Engauge Digitizer (http://www.engauge.com/) was applied to digitize and synthesize data according to the Guyot's algorithm [59]. In this study, we combined the most fully adjusted risk estimates with their $95 \%$ CIs. Quality assessment was performed by two investigators (Wei Lu and Huihui Chen) and consensus was reached on all items through detailed discussion. All included studies were scored according to the REMARK (reporting recommendations for tumor marker prognostic studies) guideline [60]. The scores ranged from 0 to 20 and studies with scores above 15 were considered to be of high quality.

\section{Data synthesis and statistical analysis}

HRs and their corresponding 95\% CI were extracted from each included study. Heterogeneity was determined using the chi-square test and the $\mathrm{I}^{2}$ test, and $p<0.10$ in combination with $\mathrm{I}^{2}>50 \%$ indicated significant heterogeneity across studies. The odds ratios (ORs) and their corresponding $95 \%$ CI were also pooled to analyze the association between ZEB family expression and clinicopathological characteristics in digestive cancer patients. A fixed-effect or random-effect model was used to pool HR or OR depending on the heterogeneity analysis (if the heterogeneity was not significant, the fixed-effect model was more appropriate, otherwise the random-effect model was applied, which would provide wider 95\% CI). The results were presented as forest plots. To estimate 
potential publication bias, Begg's funnel plots and Egger's linear regression test were performed.

Sensitivity analyses were performed to examine the impact of single study on pooled results via sequential omission of each individual study. Subgroup analyses were also conducted by cancer type, country, protein/mRNA, quality assessment score and sample size. In addition, a cumulative meta-analysis summarizing the evidence in the assessment of sample size was performed. From small to large sample size, the studies were added one at a time to pool the results sequentially. Meta-analysis was conducted using the Stata software (version 12.0; StatCorp, College Station, TX, USA). To further assess the prognostic value of ZEB1 and ZEB2 in digestive cancers, we adopted Guyot's method which derived from Kaplan-Meier survival curves a close approximation to the original individual patient data [59]. Time-to-event data from individual study were pooled to synthesize reconstructed survival curves. The log-rank test was used to compare patient survival between two groups. All the $p$-values were two-sided and $p<0.05$ was considered statistically significant unless specified.

\section{Abbreviations}

ZEB1: zinc finger E-box binding homeobox 1; ZEB2: zinc finger E-box binding homeobox 2; EMT: epithelial mesenchymal transition; OS: overall survival; DFS: disease free survival; RFS: recurrence free survival; HR: hazard ratio; OR: odds ratio; CI: confidence interval; REMARK: reporting recommendations for tumor marker prognostic studies; IHC: immunohistochemistry; qRTPCR: quantitative real time polymerase chain reaction.

\section{Author contributions}

Mao Cai, Yihua Wu had the right to grant on behalf of all authors. Wei Lu, Chongjie Huang, Kefeng Ding and Dajing Xia contributed to the conception and design of the study. Huihui Chen, Wei Lu and Chongjie Huang contributed to literature search, data extraction, statistical analysis and edition of the manuscript. All authors have commented on drafts of the manuscript and approved the final draft.

\section{CONFLICTS OF INTEREST}

The authors have declared that no competing interests existed.

\section{FUNDING} this study.

\section{REFERENCES}

1. Van Emburgh BO, Sartore-Bianchi A, Di Nicolantonio F, Siena S, Bardelli A. Acquired resistance to EGFR-targeted therapies in colorectal cancer. Molecular oncology. 2014; 8:1084-1094.

2. Stathis A, Moore MJ. Advanced pancreatic carcinoma: current treatment and future challenges. Nature reviews Clinical oncology. 2010; 7:163-172.

3. Catalano V, Labianca R, Beretta GD, Gatta G, de Braud F, Van Cutsem E. Gastric cancer. Critical reviews in oncology/ hematology. 2009; 71:127-164.

4. Torre LA, Bray F, Siegel RL, Ferlay J, Lortet-Tieulent J, Jemal A. Global cancer statistics, 2012. CA Cancer J Clin. 2015; 65:87-108.

5. Parkin DM, Bray F, Ferlay J, Pisani P. Global cancer statistics, 2002. CA Cancer J Clin. 2005; 55:74-108.

6. Van Cutsem E, Sagaert X, Topal B, Haustermans K, Prenen H. Gastric cancer. Lancet (London, England). 2016.

7. Baniak N, Senger JL, Ahmed S, Kanthan SC, Kanthan R. Gastric biomarkers: a global review. World journal of surgical oncology. 2016; 14:212.

8. Espersen ML, Olsen J, Linnemann D, Hogdall E, Troelsen JT. Clinical implications of intestinal stem cell markers in colorectal cancer. Clinical colorectal cancer. 2015; 14:63-71.

9. Kang Y, Massague J. Epithelial-mesenchymal transitions: twist in development and metastasis. Cell. 2004; 118:277-279.

10. Kalluri R. EMT: when epithelial cells decide to become mesenchymal-like cells. The Journal of clinical investigation. 2009; 119:1417-1419.

11. Hanahan D, Weinberg RA. Hallmarks of cancer: the next generation. Cell. 2011; 144:646-674.

12. Espinoza I, Miele L. Deadly crosstalk: Notch signaling at the intersection of EMT and cancer stem cells. Cancer Lett. 2013; 341:41-45.

13. Derynck R, Muthusamy BP, Saeteurn KY. Signaling pathway cooperation in TGF-beta-induced epithelialmesenchymal transition. Current opinion in cell biology. 2014; 31:56-66.

14. Polyak K, Weinberg RA. Transitions between epithelial and mesenchymal states: acquisition of malignant and stem cell traits. Nature reviews Cancer. 2009; 9:265-273.

15. Gheldof A, Hulpiau P, van Roy F, De Craene B, Berx G. Evolutionary functional analysis and molecular regulation of the ZEB transcription factors. Cellular and molecular life sciences: CMLS. 2012; 69:2527-2541.

16. Park SM, Gaur AB, Lengyel E, Peter ME. The miR-200 family determines the epithelial phenotype of cancer cells by targeting the E-cadherin repressors ZEB1 and ZEB2. Genes \& development. 2008; 22:894-907. 
17. Comijn J, Berx G, Vermassen P, Verschueren K, van Grunsven L, Bruyneel E, Mareel M, Huylebroeck D, van Roy F. The two-handed $\mathrm{E}$ box binding zinc finger protein SIP1 downregulates E-cadherin and induces invasion. Molecular cell. 2001; 7:1267-1278.

18. Aghdassi A, Sendler M, Guenther A, Mayerle J, Behn CO, Heidecke CD, Friess H, Buchler M, Evert M, Lerch MM, Weiss FU. Recruitment of histone deacetylases HDAC1 and HDAC2 by the transcriptional repressor ZEB1 downregulates E-cadherin expression in pancreatic cancer. Gut. 2012; 61:439-448.

19. Sanchez-Tillo E, Lazaro A, Torrent R, Cuatrecasas M, Vaquero EC, Castells A, Engel P, Postigo A. ZEB1 represses E-cadherin and induces an EMT by recruiting the SWI/SNF chromatin-remodeling protein BRG1. Oncogene. 2010; 29:3490-3500.

20. Brabletz S, Brabletz T. The ZEB/miR-200 feedback loop--a motor of cellular plasticity in development and cancer? EMBO Rep. 2010; 11:670-677.

21. Gregory PA, Bert AG, Paterson EL, Barry SC, Tsykin A, Farshid G, Vadas MA, Khew-Goodall Y, Goodall GJ. The miR-200 family and miR-205 regulate epithelial to mesenchymal transition by targeting ZEB1 and SIP1. Nature cell biology. 2008; 10:593-601.

22. Mejlvang J, Kriajevska M, Vandewalle C, Chernova T, Sayan AE, Berx G, Mellon JK, Tulchinsky E. Direct repression of cyclin D1 by SIP1 attenuates cell cycle progression in cells undergoing an epithelial mesenchymal transition. Molecular biology of the cell. 2007; 18:4615-4624.

23. Cai MY, Luo RZ, Chen JW, Pei XQ, Lu JB, Hou JH, Yun JP. Overexpression of ZEB2 in peritumoral liver tissue correlates with favorable survival after curative resection of hepatocellular carcinoma. PLoS ONE. 2012; 7.

24. Okugawa Y, Toiyama Y, Tanaka K, Matsusita K, Fujikawa $\mathrm{H}$, Saigusa S, Ohi M, Inoue Y, Mohri Y, Uchida K, Kusunoki M. Clinical significance of zinc finger E-box binding homeobox 1 (ZEB1) in human gastric cancer. Journal of Surgical Oncology. 2012; 106:280-285.

25. Montserrat N, Gallardo A, Escuin D, Catasus L, Prat J, Gutierrez-Avigno FJ, Peiro G, Barnadas A, Lerma E. Repression of E-cadherin by SNAIL, ZEB1, and TWIST in invasive ductal carcinomas of the breast: a cooperative effort? Human pathology. 2011; 42:103-110.

26. Zhang GJ, Zhou T, Tian HP, Liu ZL, Xia SS. High expression of ZEB1 correlates with liver metastasis and poor prognosis in colorectal cancer. Oncology Letters. 2013; 5:564-568.

27. Otsuki S, Inokuchi M, Enjoji M, Ishikawa T, Takagi Y, Kato K, Yamada H, Kojima K, Sugihara K. Vimentin expression is associated with decreased survival in gastric cancer. Oncology Reports. 2011; 25:1235-1242.

28. Bronsert P, Kohler I, Timme S, Kiefer S, Werner M, Schilling O, Vashist Y, Makowiec F, Brabletz T, Hopt UT, Bausch D, Kulemann B, Keck T, Wellner UF. Prognostic significance of Zinc finger E-box binding homeobox 1 (ZEB1) expression in cancer cells and cancer-associated fibroblasts in pancreatic head cancer. Surgery (United States). 2014; 156:97-108.

29. Dai YH, Tang YP, Zhu HY, Lv L, Chu Y, Zhou YQ, Huo JR. ZEB2 promotes the metastasis of gastric cancer and modulates epithelial mesenchymal transition of gastric cancer cells. Digestive diseases and sciences. 2012; 57:1253-1260.

30. Goscinski MA, Xu R, Zhou F, Wang J, Yang H, Huang R, Li Y, Larsen SG, Giercksky KE, Nesland JM, Suo Z. Nuclear, cytoplasmic, and stromal expression of ZEB1 in squamous and small cell carcinoma of the esophagus. APMIS. 2015; 123:1040-1047.

31. Hara J, Miyata H, Yamasaki M, Sugimura K, Takahashi T, Kurokawa Y, Nakajima K, Takiguchi S, Mori M, Doki Y. Mesenchymal phenotype after chemotherapy is associated with chemoresistance and poor clinical outcome in esophageal cancer. Oncology Reports. 2014; 31:589-596.

32. Hashiguchi M, Ueno S, Sakoda M, Iino S, Hiwatashi K, Minami K, Ando K, Mataki Y, Maemura K, Shinchi H, Ishigami S, Natsugoe S. Clinical implication of ZEB-1 and E-cadherin expression in hepatocellular carcinoma (HCC). BMC cancer. 2013; 13:572.

33. Kahlert C, Lahes S, Radhakrishnan P, Dutta S, Mogler C, Herpel E, Brand K, Steinert G, Schneider M, Mollenhauer M, Reissfelder C, Klupp F, Fritzmann J, et al. Overexpression of ZEB2 at the invasion front of colorectal cancer is an independent prognostic marker and regulates tumor invasion in Vitro. Clinical Cancer Research. 2011; 17:7654-7663.

34. Kurahara H, Takao S, Maemura K, Mataki Y, Kuwahata T, Maeda K, Ding Q, Sakoda M, Iino S, Ishigami S, Ueno S, Shinchi H, Natsugoe S. Epithelial-mesenchymal transition and mesenchymal-epithelial transition via regulation of ZEB-1 and ZEB-2 expression in pancreatic cancer. Journal of surgical oncology. 2012; 105:655-661.

35. Murai T, Yamada S, Fuchs BC, Fujii T, Nakayama G, Sugimoto H, Koike M, Fujiwara M, Tanabe KK, Kodera Y. Epithelial-to-mesenchymal transition predicts prognosis in clinical gastric cancer. Journal of Surgical Oncology. 2014; 109:684-689.

36. Okugawa Y, Inoue Y, Tanaka K, Kawamura M, Saigusa S, Toiyama Y, Ohi M, Uchida K, Mohri Y, Kusunoki M. Smad interacting protein 1 (SIP1) is associated with peritoneal carcinomatosis in intestinal type gastric cancer. Clinical and Experimental Metastasis. 2013; 30:417-429.

37. Singh AB, Sharma A, Smith JJ, Krishnan M, Chen X, Eschrich S, Washington MK, Yeatman TJ, Beauchamp RD, Dhawan P. Claudin-1 up-regulates the repressor ZEB-1 to inhibit E-cadherin expression in colon cancer cells. Gastroenterology. 2011; 141:2140-2153.

38. Sun X, Sun Z, Zhu Z, Li C, Zhang J, Xu H, Sun M. Expression of SIP1 is strongly correlated with LDHA and 
shows a significantly poor outcome in gastric cancer. Tumor Biology. 2015; 36:7521-7530.

39. Techasen A, Namwat N, Loilome W, Duangkumpha K, Puapairoj A, Saya H, Yongvanit P. Tumor necrosis factor- $\alpha$ modulates epithelial mesenchymal transition mediators ZEB2 and S100A4 to promote cholangiocarcinoma progression. Journal of Hepato-Biliary-Pancreatic Sciences. 2014; 21:703-711.

40. Terashita K, Chuma M, Hatanaka Y, Hatanaka K, Mitsuhashi T, Yokoo H, Ohmura T, Ishizu H, Muraoka S, Nagasaka A, Tsuji T, Yamamoto Y, Kurauchi N, et al. ZEB1 expression is associated with prognosis of intrahepatic cholangiocarcinoma. Journal of Clinical Pathology. 2016; 69:593-599.

41. Wu DW, Lin PL, Cheng YW, Huang CC, Wang L, Lee H. DDX3 enhances oncogenic KRAS-induced tumor invasion in colorectal cancer via the $\beta$-catenin/ZEB1 axis. Oncotarget. 2016; 7:22687-22699. doi: 10.18632/ oncotarget.8143.

42. Xia L, Huang W, Tian D, Zhang L, Qi X, Chen Z, Shang X, Nie Y, Wu K. Forkhead box Q1 promotes hepatocellular carcinoma metastasis by transactivating ZEB2 and VersicanV1 expression. Hepatology. 2014; 59:958-973.

43. Yang X, Wang Q, Dai W, Zhang J, Chen X. Overexpression of zinc finger E-box binding homeobox factor 1 promotes tumor invasiveness and confers unfavorable prognosis in esophageal squamous cell carcinoma. Tumor Biology. 2014; 35:11977-11984.

44. Yang Z, Sun B, Li Y, Zhao X, Zhao X, Gu Q, An J, Dong $X$, Liu F, Wang Y. ZEB2 promotes vasculogenic mimicry by TGF- $\beta 1$ induced epithelial-to-mesenchymal transition in hepatocellular carcinoma. Experimental and Molecular Pathology. 2015; 98:352-359.

45. Yoshida R, Morita M, Shoji F, Nakashima Y, Miura N, Yoshinaga K, Koga T, Tokunaga E, Saeki H, Oki E, Oda Y, Maehara Y. Clinical Significance of SIP1 and E-cadherin in Patients with Esophageal Squamous Cell Carcinoma. Annals of Surgical Oncology. 2015; 22:2608-2614.

46. Zhou L, Hu YL, Wu SW, Yu L, Cheng ZN, Zhu B. [Expressions of Slug, ZEB1 and KISS-1 in gastric adenocarcinoma and their clinical significance]. Journal of Southern Medical University. 2016; 36:532-537.

47. Zhou YM, Cao L, Li B, Zhang RX, Sui CJ, Yin ZF, Yang JM. Clinicopathological significance of ZEB1 protein in patients with hepatocellular carcinoma. Annals of Surgical Oncology. 2012; 19:1700-1706.

48. Jia B, Liu H, Kong Q, Li B. Overexpression of ZEB1 associated with metastasis and invasion in patients with gastric carcinoma. Molecular and Cellular Biochemistry. 2012; 366:223-229.
49. Fontemaggi G, Gurtner A, Strano S, Higashi Y, Sacchi A, Piaggio G, Blandino G. The transcriptional repressor ZEB regulates p73 expression at the crossroad between proliferation and differentiation. Mol Cell Biol. 2001; 21:8461-8470.

50. Fontemaggi G, Gurtner A, Damalas A, Costanzo A, Higashi Y, Sacchi A, Strano S, Piaggio G, Blandino G. deltaEF1 repressor controls selectively p53 family members during differentiation. Oncogene. 2005; 24:7273-7280.

51. Zhang P, Wei Y, Wang L, Debeb BG, Yuan Y, Zhang J, Yuan J, Wang M, Chen D, Sun Y, Woodward WA, Liu Y, Dean DC, et al. ATM-mediated stabilization of ZEB1 promotes DNA damage response and radioresistance through CHK1. Nature cell biology. 2014; 16:864-875.

52. Sayan AE, Griffiths TR, Pal R, Browne GJ, Ruddick A, Yagci T, Edwards R, Mayer NJ, Qazi H, Goyal S, Fernandez S, Straatman K, Jones GD, et al. SIP1 protein protects cells from DNA damage-induced apoptosis and has independent prognostic value in bladder cancer. Proceedings of the National Academy of Sciences of the United States of America. 2009; 106:14884-14889.

53. Lin SY, Elledge SJ. Multiple tumor suppressor pathways negatively regulate telomerase. Cell. 2003; 113:881-889.

54. Hill L, Browne G, Tulchinsky E. ZEB/miR-200 feedback loop: at the crossroads of signal transduction in cancer. International journal of cancer. 2013; 132:745-754.

55. Yabusaki N, Yamada S, Murai T, Kanda M, Kobayashi D, Tanaka C, Fujii T, Nakayama G, Sugimoto H, Koike M, Nomoto S, Fujiwara M, Kodera Y. Clinical significance of zinc-finger E-box binding homeobox 1 mRNA levels in peritoneal washing for gastric cancer. Molecular and clinical oncology. 2015; 3:435-441.

56. Devic S. Warburg Effect - a Consequence or the Cause of Carcinogenesis? Journal of Cancer. 2016; 7:817-822.

57. Moher D, Liberati A, Tetzlaff J, Altman DG. Preferred reporting items for systematic reviews and meta-analyses: the PRISMA statement. International journal of surgery (London, England). 2010; 8:336-341.

58. Moher D, Liberati A, Tetzlaff J, Altman DG. Preferred reporting items for systematic reviews and meta-analyses: the PRISMA statement. PLoS medicine. 2009; 6:e1000097.

59. Guyot P, Ades AE, Ouwens MJ and Welton NJ. Enhanced secondary analysis of survival data: reconstructing the data from published Kaplan-Meier survival curves. BMC medical research methodology. 2012; 12:9.

60. McShane LM, Altman DG, Sauerbrei W, Taube SE, Gion M, Clark GM. Reporting recommendations for tumor marker prognostic studies (REMARK). Journal of the National Cancer Institute. 2005; 97:1180-1184. 